\title{
PERNGARUH KINERJA KEUANGAN DAN INTELLECTUAL CAPITAL TERHADAP NILAI PERUSAHAAN YANG TERDAFTAR DI BEI
}

\author{
Nadya Variaty dan Khairina Natsir \\ Program Studi Manajemen Fakultas Ekonomi Universitas Tarumanagara, Jakarta \\ *Email: nadyavariaty96@gmail.com
}

\begin{abstract}
The purpose of this study was to determine the effect of profitability, leverage, and intellectual capital on the value of the firm of the consumers goods sectors listed in indonesian stock exchange in the periode of 2014-2018. The proxy used to measure firm value is Tobin's $Q$ method, profitability is measured by $R O A$ ratio, leverage is measured by DER ratio, and intellectual capital measured by VAHU ratio. The research method used causal research using quantitative data and purposive sampling techniques. The research sampel consisted of 11 companies with 55 observational data. Data analysis was performed using a panel regression model using E-Views 9.0 software. The results showed profitability, leverage, and intellectual capital significantly influence the value on the value of the firm in food and beverages companies in Indonesia stock exchange.
\end{abstract}

Keywords : Value of the company, profitability, leverage, intellectual capital.

\begin{abstract}
Abstrak: Tujuan dari penelitian ini adalah untuk mengetahui pengaruh profitabilitas, leverage, dan intellectual capital terhadap nilai perusahaan pada perusahaan F\&B yang terdaftar di Bursa Efek Indonesia pada periode 2014-2018. Proksi yang digunakan untuk mengukur Nilai perusahaan adalah metode Tobin's Q, profitabilitas diukur dengan ROA, leverage diukur dengan DER, intellectual capital diukur dengan VAHU. Penelitian ini merupakan penelitian kausal dengan data kuantitatif dan metode purposive sampling. Sampel penelitian adalah 11 perusahaan dengan 55 data observasi selama periode 20142018. Data dianalisis dengan model regresi data panel menggunakan perangkat lunak EViews 9.0. Hasil penelitian ini menunjukan profitabilitas, leverage, dan intellectual capital secara parsial memiliki pengaruh yang signifikan terhadap nilai perusahaan pada perusahaan food and beverages yang terdaftar di Bursa Efek Indonesia periode 20142018.
\end{abstract}

Kata kunci : Nilai Perusahaan, Profitabilitas, Leverage, Intellectual Capital

\section{LATAR BELAKANG}

Perusahaan di industri manufaktur consumer goods subsektor food and beverages yang terdaftar di Bursa Efek Indonesia merupakan salah satu subsektor yang unggul serta memiliki potensi untuk tumbuh dan berkembang saat ini hingga di masa yang akan datang. Menurut (Bella, 2018) sektor food and beverages mengalami peningkatan 
penawaran waralaba, dan terdapat kinerja positif para perusahaan yang telah membuka kesempatan bersaing di kancah internasional sehingga hal ini menjadi peluang besar dalam penerapan teknologi industri 4.0 yang dapat mendukung perkembangan ekonomi di Indonesia. Perusahaan subsektor food and baverages akan sangat diperlukan oleh masyarakat karena merupakan kebutuhan pokok yang tidak bisa ditinggalkan. Pada saat ini banyak perusahaan yang melakukan go public untuk memperkenalkan perusahaannya ke masyarakat. Maka kondisi saat ini persaingan di pasar modal sangat ketat, sehingga pihak manajemen perusahaan harus bisa memanfaatkan teknologi dan komunikasi dengan tepat untuk menarik presepsi investor sebanyak-banyaknya untuk melakukan investasi di perusahaan tersebut.

Pada era globalisasi, masyarakat sudah menyadari bahwa investasi merupakan hal yang penting untuk menunjang kehidupan yang sejahtera. Bursa Efek Indonesia mencatat sejumlah pencapaian dari kemajuan investasi di pasar modal yang mengalami peningkatan atas keinginan seseorang untuk melakukan investasi dilihat berdasarkan data single identification (SID).

Menurut (Aldin Ulum, 2020) awal tahun 2020, kondisi di beberapa negara termasuk Indonesia sedang mengalami kasus serius serta memberikan dampak pada perekonomian khususnya pasar modal yang saat ini mengalami sentimen negatif sehingga di prediksikan pergerakan IHSG tahun ini mengalami penekanan. Perusahaan menjadi imbas dari keadaan ini mengalami penurunan traksaksi khususnya pada kegiatan usaha yang memiliki hubungan dagang kebutuhan bahan baku impor dari negara lain. Perusahaan harus menerima dan memberikan stimulus serta membuat kebijakan yang tepat untuk menanggapi hal ini guna mempertahankan stabilitas dari nilai perusahaan.

Menurut (Kweon, 2008) nilai perusahaan merupakan sebuah harga saham yang beredar di pasar saham yang bersedia untuk dibeli atau dibayarkan oleh investor untuk dimiliki sebagai bukti kepemilikan sebuah perusahaan. Nilai yang tinggi dapat mempengaruhi presepsi investor secara potensial tentu mereka menjadi lebih percaya karena perusahaan yang dipilih memiliki prospek yang bagus ditandai dengan harga saham dan tingkat pengembalian investasi yang menjanjikan. Banyak faktor yang mempengaruhi dalam menentukan nilai perusahaan yaitu profitabilitas yang dihasilkan, leverage yang digunakan, dan modal intelektual yang mendukung.

Berdasarkan hasil peneliti terdahulu (Utami Fatia, 2017), menyatakan bahwa rasio profitabilitas berpengaruh positif terhadap nilai perusahaan. (Christiani, 2019) menyatakan bahwa leverage tidak memiliki pengaruh terhadap nilai perusahaan. (Sayyidah \& Saifi, 2017) menyatakan bahwa intellectual capital berpengaruh secara signifikan terhadap nilai perusahaan. Karena ditemukan adanya perbedaan hasil dari penelitian terdahulu, maka peneliti akan melakukan pengujian kembali mengenai pengaruh profitabilitas, leverage, dan intellectual capital terhadap nilai perusahaan. 


\section{KAJIAN TEORI}

Teori Nilai Perusahaan. (Salvatore, 2005). menjelaskan bahwa teori ini merupakan teori dasar yang sangat penting mengenai nilai perusahaan. Tujuan utama perusahaan adalah memaksimalkan profit yang diikuti dengan kenaikan nilai perusahaan serta dapat mensejahterakan para pemegang sahamnya sebagai prospek jangka panjang perusahaan.

Teori Keagenan. (Jensen \& Meckling, 1976) menjelaskan bahwa prinsip teori ini menggambarkan hubungan antara satu atau lebih orang (principal) yang melibatkan orang lain (agen) untuk melakukan kontrak kerja. Teori ini merupakan teori dasar yang digunakan dalam menjalankan suatu bisnis yang melibatkan pendelegasian untuk pengambilan keputusan.

Teori Signaling. (Besley, 2008:517) menjelaskan bahwa signal merupakan sebuah tindakan yang diambil oleh manajemen perusahaan guna untuk memberikan signal pemberitahuan kepada investor mengenai fungsi manajemen dalam memandang prospek perusahaan di masa depan.

Teori Planned behavior. (Ajzen, I., \& Fishbein, 1975) menjelaskan bahwa mengenai penekanan pada rasionalitas tingkah laku individu yang timbul karena adanya niat dari individu tersebut untuk berperilaku yang dipengaruhi oleh sikap, norma, dan kontrol perilaku.

Teori Sumber Daya (RBT). Teori sumber daya ini berpendapat bahwa apabila suatu perusahaan memiliki sumber daya yang strategis tentu hal itu dapat memberikan peluang emas bagi perusahaan untuk mengembangkan keunggulan kompetitif yang dimiliki. Karena sumber daya itu merupakan aset berharga bagi perusahaan dan keunggulan kompetitif itu dapat membantu menguatkan perusahaan dalam memperoleh laba (Barney, 1991).

Nilai Perusahaan. (Salvatore, 2005) mengungkapkan bahwa tujuan utama suatu perusahaan adalah untuk memaksimalkan kekayaan perusahaan, nilai yang tinggi dapat mempengaruhi presepsi investor secara potensial tentu mereka menjadi lebih percaya karena perusahaan yang dipilih memiliki prospek yang bagus ditandai dengan harga saham dan tingkat pengembalian investasi yang menjanjikan.

Profitabilitas. (Gitman, 2003) menyatakan bahwa profitabilitas adalah hubungan antara pendapatan dan biaya yang dihasilkan sebagai aset perusahaan, baik saat ini atau selama kegiatan operasi berlangsung. (Brigham \& Houston, 2014) mengungkapkan bahwa, "Profitabilitas merupakan hasil akhir dari gabungan likuiditas, hutang, dan manajemen aktiva."

Leverage. (Novari \& Lestari, 2016) dalam penelitiannya menyatakan bahwa, "Leverage merupakan salah satu kemampuan perusahaan dalam meningkatkan laba yang dapat dijadikan tolak ukur, dimana perilaku manajer dilihat dalam aktivitas meningkatkan majemen laba. Nilai perusahaan dapat dipengaruhi oleh besar kecilnya leverage atau tingkat hutang yang dihasilkan oleh perusahaan."

Intellectual Capital. (Yuniasih et.al., 2010) dalam (Handayani, 2015) mengungkapkan bahwa "tujuan utama dari modal intelektual yaitu untuk menciptakan nilai tambah (value added), dimana dalam menciptakan nilai tambah membutuhkan pengukuran yang tepat yaitu harus mempertimbangkan penggunaan capital employed (modal fisik dan modal 
keuangan) serta efisiensi dari modal intelektual terutama human capital yang memfokuskan pada modal intelektual sebagai salah satu bentuk aset tak berwujud."

\section{Kaitan antar variabel}

Profitabilitas terhadap Nilai Perusahaan. Profitabilitas memiliki keterkaitan dengan nilai perusahaan. Diketahui profitabilitas merupakan salah satu indikator yang paling popular dalam membuat keputusan investasi. Perusahaan akan selalu berupaya dapat meningkatkan profitabilitasnya sebagaimana diketahui tujuan perusahaan yaitu dapat memaksimalkan laba. Sehingga semakin tinggi rasio profitabilitas akan berpengaruh pada kenaikan nilai perusahaannya.

Leverage terhadap Nilai Perusahaan. Leverage sangat berkaitan erat dengan nilai perusahaan karena leverage digunakan sebagai tolak ukur yang tercermin dari kemampuan suatu perusahaan dalam menggunakan hutang yang dipinjam untuk mencapai tujuan perusahaan serta memaksimalkan kekayaan perusahaan dan pemegang saham, semakin kecil rasio leverage maka risiko yang ditanggung oleh perusahaan semakin kecil dan sebaliknya.

Intellectual Capital terhadap Nilai Perusahaan. Modal intelektual dianggap sebagai aset perusahaan dan secara luas dapat didefinisikan sebagai pengumpulan sumber daya yang digunakan untuk mendorong pertumbuhan serta dapat meningkatkan sumber daya untuk mengembangkan keahlian manajemen disuatu perusahaan yang dapat mempengaruhi kenaikan nilai perusahaan.

Berikut ini adalah model penelitian dalam penelitian ini yang menunjukan hubungan antara variabel independen dan variabel dependen.

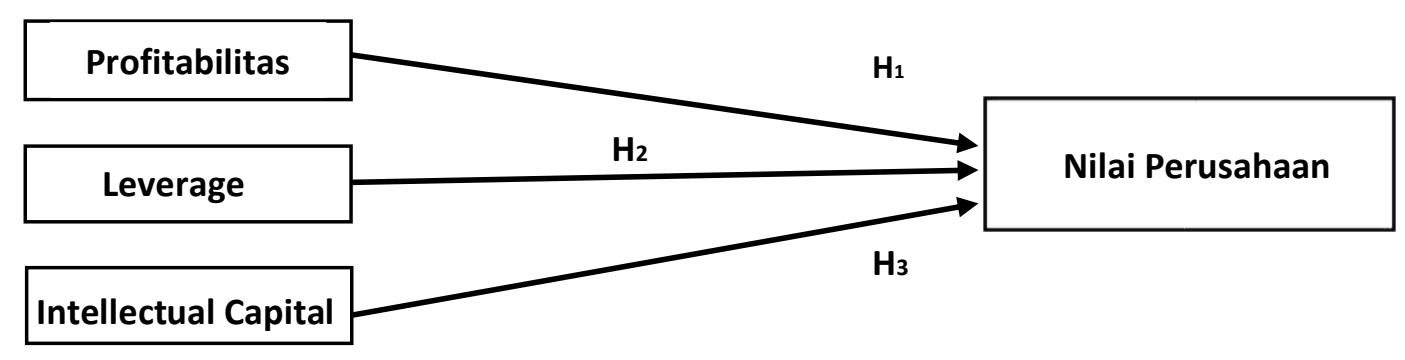

Gambar 2.1

Kerangka Pemikiran Penelitian

Hipotesis dalam penelitian ini :

H1 : Profitabilitas memiliki pengaruh terhadap Nilai Perusahaan

$\mathrm{H} 2$ : Leverage memiliki pengaruh terhadap Nilai Perusahaan

H3 : Intellectual Capital memiliki pengaruh terhadap Nilai Perusahaan 


\section{METODOLOGI}

Dalam penelitian ini pengujian yang dilakukan yaitu analisis statsitik deskriptif, uji asumsi klasik, estimasi regresi data panel (uji chow, uji hausman, dan uji lagrange), uji parsial, dan uji koefisien determinasi. Populasi yang digunakan yaitu perusahaan sektor manufaktur subsektor Food and Beverages. Sampel menggunakan metode purposive sampling, sampel yang memenuhi kriteria-kriteria yaitu 11 perusahaan yang dilihat dari 5 periode 2014-2018, sehingga jumlah observasi yaitu 55 data. kriteria dalam penelitian ini yaitu : 1) Perusahaan yang berada pada sektor f\&b yang telah terdaftar di BEI periode 2014-2018. 2) Perusahaan yang memilki laporan keuangan lengkap yang telah diaudit periode 2014-2018.

1. Operasionalisasi Variabel

a) Variabel Dependen

Variabel dependen dalam penelitian ini adalah Nilai Perusahaan yang diproksikan dengan rasio Tobin's Q dengan membandingkan seluruh aset berwujud dan tidak berwujud (Sartono, 2010).

$$
\text { Tobin's Q }=\frac{(M V E+\text { Debt })}{\text { Total Asset }}
$$

b) Variabel Independen

1. Profitabilitas

Dalam penelitian ini profitabilitas akan diproksikan dengan rasio Return On Asset (ROA) dengan membandingkan antara laba bersih dengan ratarata total aset yang dimiliki perusahaan (Brigham \& Houston, 2014).

$$
\text { ROA }=\frac{\text { Net Income }}{\text { Total Asset }}
$$

2. Leverage

Dalam penelitian ini leverage akan diproksikan dengan Debt to Equity Ratio (DER) dengan membandingkan seluruh hutang perusahaan termasuk hutang lancar dengan seluruh ekuitas yang dimiliki perusahaan (Brigham \& Houston, 2014).

$$
\text { DER } \quad=\quad \frac{\text { Total Debt }}{\text { Total Equity }}
$$

\section{HASIL UJI STATISTIK DESKRIPTIF}

Uji statistik deskriptif dari penelitian ini menunjukan nilai maksimum Q dalam penelitian ini adalah sebesar 4.809400, Nilai minimum sebesar 0.479000, Nilai mean sebesar 2.104011, nilai median sebesar 1.412400, standar deviasi pada sebesar 1.332556. Nilai maksimum profitabilitas sebesar 0.290400 , nilai minimum sebesar -0,089800, nilai mean sebesar 0,075758, nilai median sebesar 0.071700 , standar deviasi sebesar 0,079298. Nilai maksimum leverage sebesar 2.788600 , nilai minimum sebesar 0.076000 , nilai mean sebesar 0.076000 , nilai median sebesar 0.880800 , standar deviasi sebesar 0.539165 . Nilai maksimum intellectual capital 
sebesar 5.643500, nilai minimum sebesar -1.233000 , nilai mean 1.253695 , nilai median 0.854900, standar deviasi sebesar 1.532544 .

Uji Asumsi Klasik, penelitian ini hanya menguji uji multikolinieritas saja. Berdasarkan hasil uji multikolinieritas yang telah dilakukan peneliti yaitu kolerasi antara variabel kurang dari $80 \%$. Artinya, bahwa antara variabel independen pada penelitian ini tidak memiliki hubungan antar variabelnya sehingga penelitian ini tidak mengalami masalah multikolinieritas

Uji chow merupakan tahap awal dalam menentukan model terbaik pada penelitian ini yaitu antara common effect model atau fixed effect model. Hasil dari uji chow ini menunjukan model terbaik dalam penelitian ini adalah fixed effect model karena nilai probabilitas $<0,05$.

Tahap dua yaitu uji hausman untuk memilih antara random effect model atau fixed effect model. Hasil dari uji hausman ini menunjukan model terbaik dalam penelitian ini adalah random effect model karena probabilitas $>0.05$.

Tahap ketiga yaitu uji lagrange multiplier merupakan tahap terakhir dalam memperoleh hasil model terbaik antara common effect model atau random effect model. Hasil dari uji lagrange menunjukan bahwa model yang paling tepat untuk peneitian ini adalah random effet model.

Uji koefisien determinasi dalam penelitian ini menunjukan bahwa besarnya nilai adjust $r$-square sebesar 0.090896. Artinya Artinya pada variabel-variabel independen profitabilitas, leverage, dan intellectual capital dalam penelitian ini dapat memberikan kontribusi berupa informasi yang dibutuhkan sebesar $9 \%$ sisanya $91 \%$ dapat dijelaskan oleh variabel-variabel lain diluar penelitian ini.

Uji t bertujuan untuk melihat tingkat signifikansi dari pengaruh variabel independen terhadap variabel dependen dalam penelitian ini. Berikut ini adalah tabel hasil uji t dalam penelitian ini :

Tabel 1

Hasil Uji Parsial (uji t)

\begin{tabular}{ccccc}
\hline \hline Variable & Coefficient & Std. Error & t-Statistic & Prob. \\
\hline \hline C & 1.489910 & 0.378860 & 3.932611 & 0.0003 \\
ROA & 5.617720 & 0.737678 & 7.615413 & 0.0000 \\
DER & 0.383680 & 0.135138 & 2.839164 & 0.0065 \\
VAHU & -0.117638 & 0.017272 & -6.810771 & 0.0000 \\
\hline \hline
\end{tabular}

Sumber : E-Views 9

Berdasarkan besarnya nilai probabilitas pada variabel Profitabilitas yang diproksikan dengan ROA lebih kecil dari tingkat signifikansinya yaitu sebesar $0.0000<0,05$. Artinya profitabilitas memiliki pengaruh sigifikan terhadap nilai 
perusahaan. Besarnya nilai probabilitas pada variabel Leverage yang diproksikan dengan DER lebih kecil dari tingkat signifikansinya yaitu sebesar $0.0065<0,05$. Artinya Leverage memiliki pengaruh signifikan terhadap nilai perusahaan. Besarnya nilai probabilitas pada variabel Intellectual Capital yang diproksikan dengan VAHU lebih besar dari tingkat signifikansinya yaitu sebesar $0.0000<0,05$. Artinya intellectual capital memiliki penaruh signifikan terhadap nilai perusahaan.

\section{DISKUSI}

Berdasarkan hasil pengujian hipotesis yang telah dilakukan, variabel profitabilias (ROA) memiliki pengaruh terhadap nilai perusahaan. Hipotesis sejalan dengan penelitian (Utami Fatia, 2017), sebaliknya tidak sejalan dengan penelitian (Setyawan, 2015). Variabel leverage (DER) memiliki pengaruh terhadap nilai perusahaan. Hipotesis sejalan dengan penelitian (Utami Fatia, 2017), sebaliknya penelitian tidak sejalan dengan penelitian (Christiani, 2019). Variabel intellectual capital memiliki pengaruh terhadap nilai perusahaan. Hipotesis sejalan dengan penelitian (Sayyidah \& Saifi, 2017).

\section{PENUTUP}

Hasil penelitian ini menunjukan bahwa profitabilitas, leverage, dan intellectual capital secara parsial memiliki pengaruh signifikan terhadap nilai perusahaan pada perusahaan food and beverages yang terdaftar di Bursa Efek Indonesia periode 2014-2018.

Keterbatasan dalam penelitian ini antara lain : 1) periode yang digunakan hanya dari tahun 2014-2018 saja. 2) perusahaan yang sesuai kriteria terbatas hanya 11 perusahaan. 3) variabel yang digunakan hanya profitabilitas, leverage, dan intellectual capital.

Saran dalam penelitian ini antara lain : 1) Bagi peneliti selanjutnya sebaiknya memperluas variabel independen dalam menguji nilai perusahaan seperti kebijakan dividen, ukuran perusahaan, kepemilikan manajerial, manajemen risiko, dll dan Menggunakan perusahaan pada sektor yang berbeda karena terdapat banyak sektor yang terdaftar di Bursa Efek Indonesia. 2) Bagi perusahaan, perusahaan harus mampu memaksimalkan profitabilitas (ROA) dengan meningkatkan aktiva total dan laba bersih untuk meningkatkan laba bersih salah satunya dapat meningkatkan penjualan, penggunaan hutang dapat di minimumkan dengan cara menurunkan biaya produksi seingga perusahaan tidak perlu menggunakan hutang secara berlebihan, dan memanfaatkan modal intelektual guna meningkatkan kinerja perusahaan yang dapat menciptakan value positif untuk perusahaan tersebut. 3) Bagi investor, penelitian ini dapat dijadikan acuan untuk mengambil keputusan investasi yang tepat dalam menilai perusahaan mana yang layak untuk diipilih sebagai sumber investasi dana kalian.

\section{DAFTAR PUSTAKA}

Ajzen, I., \& Fishbein, M. (1975). Belief, Attitude, Intention, and Behavior: An Introduction to Theory and Research. MA: Addison-Wesley. 
Aldin Ulum, I. (2020). Prediksi IHSG 2020. In katadata.co.id (p. 15 Februari 2020). https://katadata.co.id/berita/2020/02/15/anjlok-648-sejak-awal-tahun-beginiprediksi-ihsg-hingga-akhir-2020

Barney, J. (1991). Firm resources and sustained competitive advantage. Journal of management. Journal of Management, 17(1), 99-120. https://doi.org/0803973233

Bella, A. (2018). Sektor Food \& Beverages menjadi contoh penerapan industri 4.0 di Indonesia. In Marketeers (p. 23 Maret 2018).

Besley, S. dan B. E. F. (2008). Essentials of Managerial Finance. USA, SouthWestern.

Brigham, E. F., \& Houston, J. F. (2014). Dasar-Dasar Manajemen Keuangan : Essetials Of Financial Management. In Salemba Empat. https://doi.org/10.1145/2505515.2507827

Christiani, L. dan V. H. (2019). Pengaruh Kepemilikan Manajerial, Komite Audit, Leverage, Profitabilitas, Dan Ukuran Perusahaan Terhadap Nilai Perusahaan Dengan Manajemen Laba Sebagai Variabel Moderasi. In Jurnal Magister Akuntansi Trisakti. https://doi.org/10.25105/semnas.v0i0.5824

Gitman, L. (2003). Principles of managerial finance (10th ed.). Boston, Addison wesley.

Handayani, I. (2015). PENGARUH MODAL INTELEKTUAL TERHADAP NILAI PERUSAHAAN MANUFAKTUR YANG TERDAFTAR DI BURSA EFEK INDONESIA Indrie. E-Jurnal Katalogis, 3(9), 21-30.

Jensen, M. C., \& Meckling, W. H. (1976). Theory of the firm: Managerial behavior, agency costs and ownership structure. Journal of Financial Economics, 3(4), 305-360. https://doi.org/10.1016/0304-405X(76)90026-X

Kweon, J. A. (2008). Manajemen Keuangan (Edisi 10). PT. Macanan Jaya Cemerlang, Jakarta.

Novari, P., \& Lestari, P. (2016). Pengaruh Ukuran Perusahaan, Leverage, Dan Profitabilitas Terhadap Nilai Perusahaan Pada Sektor Properti Dan Real Estate. E-Jurnal Manajemen Universitas Udayana, 5(9), 5671-5694.

Salvatore, D. (2005). Ekonomi Manajerial dalam Perekonomian Global. Jakarta, PT Salemba Empat.

Sartono, A. (2010). Menejemen Keuangan Teori dan Aplikasi (Edisi 4). BPFE Yogyakarta.

Sayyidah, U., \& Saifi, M. (2017). PENGARUH INTELLECTUAL CAPITAL TERHADAP NILAI PERUSAHAAN DENGAN PROFITABILITAS SEBAGAI VARIABEL MODERASI (Studi Pada Perusahaan Sub Sektor Property Dan Real Estate Di Bursa Efek Indonesia Periode 2013-2015). Jurnal Administrasi Bisnis S1 Universitas Brawijaya, 46(1), 163-171.

Setyawan, N. P. (2015). PENGARUH PROFITABILITAS, SOLVABILITAS, 
UKURAN PERUSAHAAN DAN LIKUIDITAS TERHADAP NILAI PERUSAHAAN PADA PERUSAHAAN MANUFAKTUR DI INDONESIA PERIODE TAHUN 2011-2015.

Utami Fatia, V. (2017). Pengaruh Kebijakan Dividen, Profitabilitas,Leverage, dan size terhadap Nilai Perusahaan. Accounting Analysis Journal, 1, 43.

www.idx.co.id 